\title{
THE ROLE OF FASHION IN EVERYDAY LIFE
}

\author{
Anastasiia Khokhloval, Larysa Klymanska ${ }^{2}$ \\ Lviv Polytechnic National University, Lviv, Ukraine \\ ${ }^{1}$ student, Department of Sociology and Social Work \\ ${ }^{2}$ doctor of Political Science, Professor, Department of Sociology and Social Work
}

Background: The role of fashion is a recent topic in sociological discourse, even though it plays the main role in visual representation of an individual and how the person will be perceived in a society. This phenomenon involves social imitation and directly impacts on social interactions.

Purpose: to establish the real role of fashion in everyday lives of people in Ukraine.

Methods: Theoretical research methods were used to analyze the current role of fashion as a social phenomenon in everyday life. The empirical method of qualitative sociological studies was used to analyze personal experience and usage of fashion in the study of the topic "The role of fashion in people's everyday life".

Results: An analysis of the transcripts of in-depths interviews confirmed our hypothesis about the impacts of fashion on everyday interactions and on forming an opinion about others based on their looks.

Conclusion: Thus, the results of the study shows that fashion plays a significant role in the lives of people as it.

Keywords: fashion, social imitation, interaction, everyday life.

В епоху масового споживання одним із ключових моментів стало споживання модних атрибутів. Це передусім пов'язано з тим, що нині поширений «візуалізаційний» тип сприйняття, де зовнішній вигляд, естетичні вподобання, в тому числі і щодо модних атрибутів, визначають, до якого соціального класу, статусу та положення індивіди відносять або бажають себе відносити. В цьому випадку мода відіграє роль комунікативного каналу, за допомогою якого індивіди транслюють соціальну значиму інформацію через атрибути моди.

Дослідження моди як соціокультурного феномену проводили такі західні і вітчизняні вчені як I. Кант, А. Сміт, Т. Адорно, Г. Тард, Г. Зіммель, Т. Веблен, Р. Барт, Д. Рісмен, Ж. Бодрійяр, Г. Блумер, А. Гофман, Л. Дихнич, Т. Ніколаєва, Ю. Легенький, Б. Паригін, Б. Поршнєв, Р. Гузявічуте та Т. Козлова, М. Яковлєва, Н. Копилова, К. Міхалева.

В теоретичних доробках видатних вчених-соціологів, увага зосереджена передусім на соціальній основі поширення моди, а саме на аспекті соціального наслідування (Гурова, 2011). Використовуючи моду, індивіди намагаються уособити себе з референтною групою, наслідувати іiі зовнішність, одяг, що дозволяє ідентифікувати себе з бажаною групою.

Використання моди у повсякденному житті пов'язують з комунікативним аспектом. Мода слугує засобом самовираження індивідів у соціальних взаємодіях. Через споживання модних атрибутів відбувається регуляція того, як мають поводитися індивіди у повсякденному житті, розділяючи їх за певними віковими та гендерними критеріями або іншими соціальнодемографічними показниками. Прийнято вважати, що найбільше піддається впливу моди така категорія населення як молодь, оскільки молодь активно набуває та засвоює соціальні ролі, норми і цінності. Відповідно схильність молоді до загальних інновацій та експериментів, утвердження власного стилю ініціює модну поведінку та споживання модних атрибутів [Ильясова, 2016]. Через моду можна виразити слідування певним нормативним взірцям та свою участь у соціальному житті. Модні стандарти в свою чергу наділені нормативною «диктатурою», що створюють соціальні рамки цінностей та норм, звичок та правил.

Для кращого розуміння ролі моди у повсякденному житті у листопаді-грудні 2019 року ми провели навчальне якісне соціологічне дослідження на тему “Роль моди в житті людини”. Завдяки

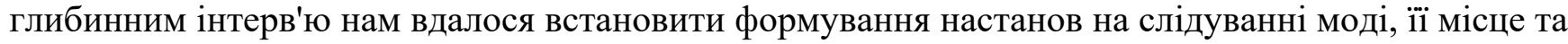


роль у житті індивіда. За мету було поставлено встановити роль моди у повсякденному житті інформантів. В дослідженні було використано так звану теоретичну вибірку, тобто відбір інформантів на основі їх характеристик, а саме: типового інформанта (жінка вікової групи 18-30 років, що цікавиться та слідкує за модою), специфічного (ексклюзивного) інформанта (молода людина, що з ідеологічних причин не слідкує та не цікавиться модою), а також нетипового інформанта (жінка вікової групи 45-60 років, що цікавиться та слідкує за модою).

Перед проведенням глибинних інтерв'ю було виділено наступні категорії: 1) «роль та місце моди у житті людини», 2) «інтерпретація моди, іiї символів та значень», 3) «способи формування модних настанов», 4) «вплив моди на повсякденні взаємодії».

За категорією «роль та місце моди у житті людини»: два інформанта з трьох, які були залучені до дослідження, стверджували, що слідування модним стандартам додає їм впевненості та значущості, мода допомагає їм ставитися до себе краще, покращує самооцінку та настрій: «мені здається, щуо я одразу така дуже гарна, на мене всі звертають увагу і мені ие додає впевненості», «набагато впевненішою виглядаю... що я можу все в цчей час». Один інформант стверджував, що слідування моді викликає в нього негативні враження «зараз купа народу як сіра маса таскають такі речі», проте так само інформант погодився, що речі мають певний сентиментальний характер: «ношу те, щзо мені подобається...і при ицьому изі речі зазвичай мають особистий характер». Відповідно всі інформанти наголосили на тому, що одяг безпосередньо впливає на настрій, на самовідчуття.

За категорією «способи формування модних настанов» два інформанта стверджували, що соціальне оточення та бажання бути кращим спонукало слідувати моді: ««одна однокласниия, за якою завжди бігали хлопиі, з якою завжди всі хотіли дружити, і вона завжди була вдягнена дуже модно... I тоді хотілося також виглядати гарно на ї̈ фоні», «я завжди хотіла, щуоб на мене заглядали, щџоб мені заздрили дівчата... і так хотілося так само виглядати, модно, сучасно $і$ по-дорослому». Відповідно до цього значний вплив на формування модних настанов відіграє соціальне наслідування, а також референтна група. Один інформант стверджував, що бажання вирізнитися спонукало його не слідувати модним стандартам: «Ну щзо за брєд, чому люди виглядають настільки однотипно $і$ ніхто не хоче якось виокремитись?». Важливим аспектом моди можна вважати уніфікаційні процеси, які поширюються серед споживачів модних атрибутів, а також вираження слідування загальним нормам і правилам. Настанови на модну поведінку відбуваються у ранньому підлітковому віці та пов'язані 3 бажанням бути схожим на когось «кращого». Відповідно у моді проявляється елемент наслідування, який спонукає притримуватися модних настанов.

За категорією «інтерпретація моди, їі символів та значень»: всі три інформанти виразили свою думку, що мода несе у собі символи, які інтерпретують інші. Так, два інформанти навели приклади ситуацій, коли їхній зовнішній вигляд та одяг викликав у інших людей негативні враження, що викликало у інформантів почуття сорому та невдоволеності собою: «сказала, щзо... взагалі-то на день народження можна і нарядно вдягатися, а не у спортивному, як ти приїхати. I мені тоді стало соромно», «I я тоді аж заплакала, бо мені було дуже незручно», а один інформант уникає ситуації, коли треба вдягатися модно і ще за певними стандартами «випускний, на який я не пішов... Тому що... Всі занадто виряджаються». Усі інформанти були свідомі того, що їхній одяг носить у собі символи, які викликають у інших людей визначені реакції. Відповідно до цього в соціальних взаємодіях створюються соціальні очікування щодо зовнішнього вигляду іншого, які викликають у індивідів бажання відповідати тим нормам та не викликати негативних реакцій в оточенні. Страх бути засудженим іншими змушує індивідів відтворювати модні стандарти.

У категорії «вплив моди на повсякденні взаємодії» три інформанти надавали значення одягу, особливо модному, іншої людини, отримували від одягу певну інформацію про інших. Два інформанти стверджували, що за одягом розуміють, чи людина має в пріоритеті красу, яке соціальне положення займає, визначали за одягом привабливість іншої людини: «я щее по одязі зрозуміла, щуо ми з нею не зійдемося. Тому щз вона прям дуже творчою виглядала. До речі, так $і$ сталося», «мені подобаються людина, щуо модно вдягнена ... і враження від неї дуже-дуже приємні». Один інформант 
стверджував, що негативно оцінює людей, що слідують моді «вона належить до сірої маси... I не може якось реалізувати в ц̧ьому плані, показати себе. І тому вона думає, щзо краси і унікальності ій додають галімі шмотки з масмаркету, які вважаються модними, але насправді такого результату циим не добиваються». Відповідно всі три інформанти визнають вплив модного одягу на їхні враження від іншої людини та формують перші вражання, а також безпосередньо визначають подальше спілкування з іншою людиною. Це пов'язано передусім з тим, що за допомогою одягу іншої людини, можна передбачити, чи слідує людина тим самим правилам, що і інформант.

Інформанти також висловили свої думки про те, що мода має демонстративний характер, проте за допомогою неї у повсякденних взаємодіях складно повністю проявити особистість: всі три інформанти стверджували, що остаточне враження від людини отримують не через одяг «...зустрічають по одьожке, провожають по уму... Треба завжди старатися свою особистість показати словами, язиком, думками, правильними чи неправильними... А одяг не має відігравати значну роль у цььому...», «...ми зустрічаємо людей по одягу, а проводжаємо по розуму...Якщо вона модна людина $і$ то ж не означає, щзо в неї характер золотий...», «Та дівчина дуже гарно виглядає, якщчо ще якісь ще і дорогі речі, то думаю: «Боже, вона ще і багата».. Як ій повезло, вона має смак $і$ в неї є гроші...». Було виявлено, що усі інформанти погоджуються з тим, що мода та модний одяг слугують інструментом для створення першого враження. Цей аспект потребує подальшого дослідження.

Отже, результати дослідження виявили те, що мода відіграє важливу роль у комунікативному аспекті повсякденного життя. За допомогою моди формується першочергове уявлення про індивіда, а також відбувається створення першого враження. Іншою вагомою роллю моди як інструменту в повсякденному житті є ідентифікація себе за допомогою модних атрибутів з референтною групою.

\section{References}

Gurova, O. (2011). Sociology of fashion: review of the classic conceptions. Social studies, 8, 72-82.

Iliasova, S. (2016). Fashion as a form of group behavior. Social studies, 1, 32-41.

\section{Список використаних джерел}

Гурова, О. (2011). Социология моды: обзор классических концепций. Социологические исследования, $8,72-82$.

Ильясова, С. Ф. (2016). Мода как форма группового поведения. Социальные исследования, 1, $32-41$.

\section{Contact information:}

Khokhlova Anastasiia

anastasiia.khokhlova.so.2016@1pnu.ua

Klymanska Larysa

Larysa_kl@ukr.net 